Article

\title{
Chemical Composition of Lipophilic Bark Extracts from Pinus pinaster and Pinus pinea Cultivated in Portugal
}

\author{
Joana L. C. Sousa ${ }^{1,2,+} \mathbb{D}$, Patrícia A. B. $\operatorname{Ramos}^{1,2,+} \mathbb{D}$, Carmen S. R. Freire ${ }^{1}$, Artur M. S. Silva ${ }^{2} \mathbb{D}$ \\ and Armando J. D. Silvestre ${ }^{1, *(D)}$ \\ 1 CICECO, Department of Chemistry, University of Aveiro, 3810-193 Aveiro, Portugal; \\ joanasousa@ua.pt (J.L.C.S.); patriciaaramos@ua.pt (P.A.B.R.); cfreire@ua.pt (C.S.R.F.) \\ 2 QOPNA, Department of Chemistry, University of Aveiro, 3810-193 Aveiro, Portugal; artur.silva@ua.pt \\ * Correspondence: armsil@ua.pt; Tel.: +351-234-370-711; Fax: +351-234-370-084 \\ + Both authors contributed equally to this work.
}

Received: 25 November 2018; Accepted: 8 December 2018; Published: 11 December 2018

\begin{abstract}
The chemical composition of lipophilic bark extracts from Pinus pinaster and Pinus pinea cultivated in Portugal was evaluated using gas chromatography-mass spectrometry. Diterpenic resin acids were found to be the main components of these lipophilic extracts, ranging from $0.96 \mathrm{~g} \mathrm{~kg}^{-1} \mathrm{dw}$ in P. pinea bark to $2.35 \mathrm{~g} \mathrm{~kg}^{-1} \mathrm{dw}$ in P. pinaster bark. In particular, dehydroabietic acid (DHAA) is the major constituent of both P. pinea and P. pinaster lipophilic fractions, accounting for $0.45 \mathrm{~g} \mathrm{~kg}^{-1} \mathrm{dw}$ and $0.95 \mathrm{~g} \mathrm{~kg}^{-1} \mathrm{dw}$, respectively. Interestingly, many oxidized compounds were identified in the studied lipophilic extracts, including DHAA-oxidized derivatives (7-oxo-DHAA, $7 \alpha / \beta$-hydroxy-DHAA, and 15-hydroxy-DHAA, among others) and also terpin (an oxidized monoterpene). These compounds are not naturally occurring compounds, and their formation might occur by the exposure of the bark to light and oxygen from the air, and the action of micro-organisms. Some of these compounds have not been previously reported as lipophilic constituents of the bark of the referred pine species. Other constituents, such as aromatic compounds, fatty acids, fatty alcohols, and sterols, are also present in the studied extracts. These results can represent an opportunity to valorize P. pinaster and P. pinea by-products as a primary source of the bioactive resin acids that are integrated into the current uses of these species.
\end{abstract}

Keywords: bark; biorefinery; diterpenic resin acids; GC-MS analysis; Pinus pinaster; Pinus pinea

\section{Introduction}

Pinus pinaster and Pinus pinea are the two dominant pine species in Portugal, occupying ca. 714,000 and 176,000 ha, which represent $23 \%$ and $6 \%$ of the total forest area, respectively [1]. These conifers have an important impact on the national economy due to their vast applicability in timber and resin industries and also in pulp fibers production [2]. P. pinea is also cultivated because of the high commercial value of its edible seeds, which have high nutritional value and are a traditional component of the Mediterranean diet [2].

The bark of these two Pinus species consists in an interesting raw material, since it is produced in large amounts (6481 and $253 \mathrm{k}$ ton year ${ }^{-1}$ of P. pinaster and P. pinea bark, respectively [3]) as a by-product of the abovementioned industries. These bark residues are simply burnt to produce energy or used as an organic substrate for plant nurseries after composting. An interesting alternative is their exploitation as a source of added-value chemicals, such as bioactive ingredients with potential nutraceutical applications, which ultimately can be integrated into the referred traditional applications in a biorefinery perspective [4] in order to maximize the biomass value. 
Resin acids (mainly abietane-type resin acids, including the abietic, neoabietic, palustric, and levopimaric acids, and minor amounts of pimarane-type resin acids, including the pimaric, isopimaric, and sandaracopimaric acids) are the major components of Pinus spp. wood resin [5]. Small amounts of dehydroabietic acid (DHAA), obtained by dehydrogenation of abietane-type resin acids, can also be found in wood resins. These compounds have been exploited as important commodities for the chemical industry [5]. In addition, they play an important role in the chemical defense of conifers. Many examples show a relationship between conifer diterpenic acid content and a tree's resistance to potential herbivores and pathogens [6]. Furthermore, resin acids display important beneficial properties for human health, being the antimicrobial, antiulcer, and cardiovascular activities the most representative ones $[7,8]$.

Due to the mentioned significant biological properties, the search for new natural and synthetic resin acid derivatives has been an active research field. Most of these compounds have been tested for their cytotoxicity against cancer cells [9-14], and their antioxidant $[9,15]$, antiviral $[10,11,16]$, antimycotic [10], and gastroprotective [12] activities.

Resin acids can also be found in the lipophilic extracts of different morphological parts of several Pinus spp. [17-25], including the bark of Pinus nigra [21], the Turkish P. pinea L. [23], and the Pakistani Pinus wallichiana, Pinus roxburghii, and Pinus gerardiana [25]. Among the resin acids that have been identified in bark lipophilic extracts are the pimaric, sandaracopimaric, levopimaric, palustric, isopimaric, abietic, dehydroabietic, and neoabietic acids, and the 7-oxodehydroabietic, 16-hydroxydehydroabietic, and 8,15-isopimaridien-18-oic acids [21,23,25]. Additionally, other lipophilic constituents of Pinus spp. bark, such as several fatty acids, aliphatic alcohols, sterols (mainly $\beta$-sitosterol), $\beta$-caryophyllene, and some aromatic compounds (ferulic acid, vanillin, etc.), have also been detected $[21,23,25]$.

Although there are some compositional studies of bark from P. pinaster [26,27] and P. pinea [28] cultivated in Portugal, a detailed chemical characterization of their lipophilic components is still missing. Therefore, in the present work, dichloromethane (DCM) extracts of bark from the referred Pinus spp. collected from the Centre of Portugal were prepared and analyzed by gas chromatography-mass spectrometry (GC-MS). The main aim was to evaluate the exploitation potential of these industries' by-products as an alternative source of bioactive compounds (e.g., resin acids) for further applications, such as nutraceutical and cosmetic usages. An interesting example of a possible application of resin-acids-rich natural extracts is Progres ${ }^{\circledR}$, the only resin-acids-based product that is used for animal feed, which comes from the Finnish forest and has proven beneficial effects on the productivity of animals [29-31].

\section{Materials and Methods}

\subsection{Chemicals}

Dichloromethane (p.a., $\geq 99$ purity) was obtained from Fisher Chemicals (Pittsburgh, PA, USA). Pyridine (anhydrous, 99.8\% purity), N,O-bis(trimethylsilyl)trifluoroacetamide (derivatization grade), chlorotrimethylsilane ( $\geq 99 \%$ purity), $\alpha$-terpineol $(90 \%$ purity), hexadecenoic acid $(99 \%$ purity), nonadecan-1-ol (99\% purity), stigmasterol (95\% purity), tetracosane ( $99 \%$ purity), and vanillin ( $99 \%$ purity) were purchased from Sigma-Aldrich (Madrid, Spain). Betulinic acid ( $98 \%$ purity) was supplied by Chemos (Regenstauf, Germany). Dehydroabietic acid (DHAA) (99\% purity) was obtained from Helix Biotech (Vancouver, BC, Canada).

\subsection{Samples' Preparation and Extraction}

P. pinaster and P. pinea bark samples were collected from standing trees cultivated in the Aveiro region, Portugal, in January 2017, and were air-dried for 2 weeks. Thereafter, the samples were ground and sieved to a particle size lower than $1 \mathrm{~mm}$. Milled bark samples (7-10 g dry weight $(\mathrm{dw})$ ) were Soxhlet-extracted with dichloromethane $(175 \mathrm{~mL})$ for $8 \mathrm{~h}$. The extraction yield was determined by 
weighting the extract's mass and expressed as a percentage of dry biomass $(\% w / w)$. The extracts were prepared in duplicate.

\subsection{The GC-MS Analysis}

Before the GC-MS analysis, nearly $20 \mathrm{mg}$ of each dried sample was trimethylsilylated in $250 \mu \mathrm{L}$ pyridine containing $0.3 \mathrm{mg}$ of tetracosane (internal standard) through the addition of $250 \mu \mathrm{L}$ of $\mathrm{N}, \mathrm{O}$-bis(trimethylsilyl)trifluoroacetamide and $50 \mu \mathrm{L}$ of chlorotrimethylsilane. The mixture was kept at $70{ }^{\circ} \mathrm{C}$ for $30 \mathrm{~min}$ [32].

GC-MS analyses were carried out in a GC-MS-QP2010 Ultra (Shimadzu, Japan), and compounds were separated in a DB-1 J\&W capillary column $(30 \mathrm{~m} \times 0.32 \mathrm{~mm}$ inner diameter, $0.25 \mu \mathrm{m}$ film thickness), using helium as the carrier gas $\left(40 \mathrm{~cm} \mathrm{~s}^{-1}\right)$. The chromatographic conditions were as follows: initial temperature, $80^{\circ} \mathrm{C}$ for $5 \mathrm{~min}$; temperature rate, $4{ }^{\circ} \mathrm{C} \mathrm{min}^{-1}$ up to $260^{\circ} \mathrm{C}, 2{ }^{\circ} \mathrm{C} \mathrm{min}-1$ up to $285^{\circ} \mathrm{C}$, which was maintained for $10 \mathrm{~min}$, and $2{ }^{\circ} \mathrm{C} \mathrm{min}^{-1}$ up to $295^{\circ} \mathrm{C}$, which was maintained for $4 \mathrm{~min}$; injector temperature, $250^{\circ} \mathrm{C}$; transfer-line temperature, $290^{\circ} \mathrm{C}$; split ratio, 1:60. The mass spectrometer was operated in the electron impact mode with an energy of $70 \mathrm{eV}$, and data were collected at a rate of $1 \mathrm{scan} \mathrm{s}^{-1}$ over a range of $m / z 33-700$. The ion source was kept at $250^{\circ} \mathrm{C}$ [33].

Compounds were identified by comparing their mass spectra (MS) with the equipment's mass spectral library (NIST Mass Spectral Library), with data from the literature [34-43], and by the co-injection of standards.

For the quantitative analysis, the GC-MS apparatus was calibrated with pure reference compounds that were representative of the major lipophilic extracts' components, namely $\alpha$-terpineol, dehydroabietic acid, vanillin, hexadecanoic acid, nonadecan-1-ol, stigmasterol, and betulinic acid, in relation to tetracosane (the internal standard), which allowed us to determine the respective response factors. Compounds were quantified using tetracosane as an internal standard, and their abundance is expressed as $\mathrm{mg} \mathrm{kg}^{-1} \mathrm{dw}$ of bark.

Two aliquots of each extract were analyzed, and the results are represented as the average of the concordant values that were obtained for the two aliquots of the two extracts in each sample (less than $5 \%$ variation between aliquots of the same sample, and between extracts of the same sample).

\section{Results and Discussion}

\subsection{The Extraction Yield}

The dichloromethane extraction yield of P. pinaster bark $(2.56 \pm 0.11 \% w / w)$ was slightly higher than that of $P$. pinea bark $(1.951 \pm 0.002 \% w / w)$. Both values were within the lipophilic extracts yield range reported in earlier works for bark of P. pinaster $(1.1-4.0 \% w / w)[26,27]$ and P. pinea $(2.1 \%$ $w / w)$ [28] grown in Portugal.

\subsection{The Chemical Characterization of Lipophilic Fractions Derived from the P. pinaster and P. pinea Barks}

Five major families of lipophilic components were identified and quantified in the lipophilic extracts from the bark of P. pinaster and P. pinea by GC-MS. These were terpenic compounds, aromatic compounds, fatty acids, long-chain aliphatic alcohols (LCAAs), and sterols, as demonstrated in Figures 1 and 2 and detailed in Table 1. The total content of identified compounds varied between $2910 \mathrm{mg} \mathrm{kg}^{-1} \mathrm{dw}$ in P. pinea bark and $4746 \mathrm{mg} \mathrm{kg}^{-1} \mathrm{dw}$ in P. pinaster bark. Terpenes are the main family present in these extracts, ranging from $965 \mathrm{mg} \mathrm{kg}^{-1} \mathrm{dw}$ in P. pinea bark to $2865 \mathrm{mg} \mathrm{kg}^{-1} \mathrm{dw}$ in P. pinaster bark, which accounted for $33 \%$ and $60 \% w / w$ of the total content of identified compounds, respectively. 


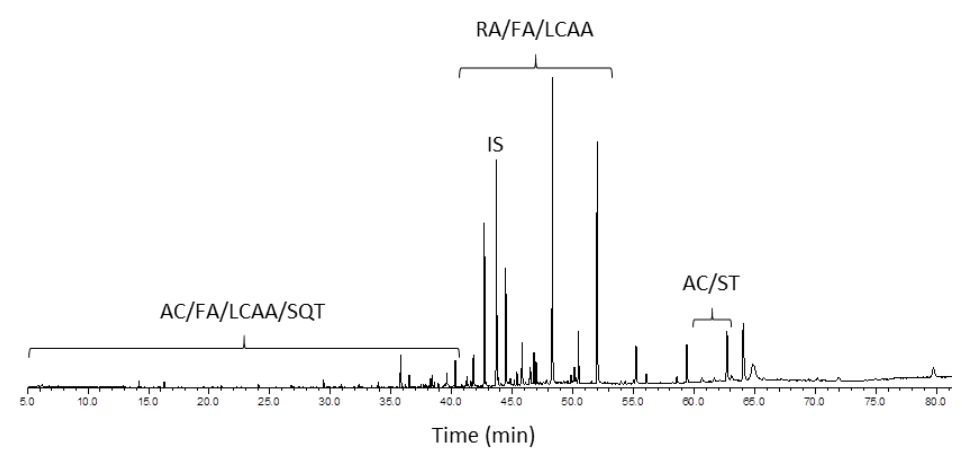

Figure 1. A GC-MS chromatogram of a Pinus pinea bark trimethylsilyl-derivatized dichloromethane extract. Abbreviations: AC, aromatic compounds; FA, fatty acids; IS, internal standard; LCCA, long-chain aliphatic alcohols; RA, resin acids; SQT, sesquiterpenes; ST, sterols.

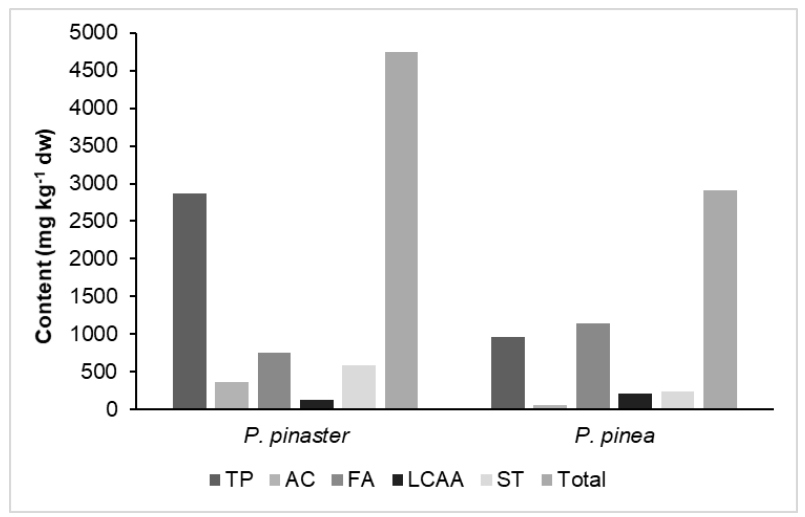

Figure 2. The major families of lipophilic components that were identified in the bark DCM extracts from Portuguese P. pinaster and P. pinea. Abbreviations: AC, aromatic compounds; FA, fatty acids; LCAA, long-chain aliphatic alcohols; ST, sterols; TP, terpenes.

\subsubsection{Terpenic Compounds}

Resin acids represent the major terpenic subclass present in the P. pinaster and P. pinea bark lipophilic fractions (Table 1), contributing $50 \%$ and $33 \% w / w$ of the total content of identified compounds, respectively. At a considerably lower abundance, betulin was the only pentacyclic triterpene identified in the P. pinaster bark extracts. Monoterpenes were also found in minor amounts, followed by sesquiterpenes.

Two groups of tricyclic diterpenic compounds were found in the studied Pinus spp. bark lipophilic extracts (Table 1), namely nine abietane-type and three pimarane-type resin acids (Figure 3). In fact, abietane-type resin acids were the most abundant components in the bark of the studied Pinus species, followed by pimarane-type resin acids.

DHAA (5) was found to be the most abundant component in bark of the studied Pinus species, representing $49 \%$ and $57 \% w / w$ of the total content of abietane-type resin acids in the P. pinaster and $P$. pinea bark samples, respectively (Table 1). Interestingly, this compound is only a minor constituent of fresh conifer resin; however, its abundance increases with aging, which results from the oxidation pathways of the abietadiene-type precursors (Scheme 1) [6,38,44]. Furthermore, the formation of DHAA might result from exposure to light and oxygen from the air. In addition, other DHAA oxidation derivatives were identified in the studied Pinus spp. extracts, namely $7 \alpha / \beta$-hydroxy-DHAA (7 and 8), 7-oxo-DHAA (9), and other oxidation products (4 and 10-12) (Figure 3). 
Table 1. The chemical composition of the lipophilic bark fractions from P. pinaster and P. pinea cultivated in Portugal (semi-quantitative data expressed in $\mathrm{mg} \mathrm{kg}^{-1} \mathrm{dw}$ ). ${ }^{1}$

\begin{tabular}{|c|c|c|c|c|}
\hline RT (min) & No. & Compound & P. pinaster & P. pinea \\
\hline & & Terpenic compounds & 2865 & 965 \\
\hline & & Diterpenic resin acids & 2353 & 960 \\
\hline & & Pimarane-type resin acids & 399 & 166 \\
\hline 41.26 & 1 & Pimaric acid & 217 & 27 \\
\hline 41.59 & 2 & Sandaracopimaric acid & 54 & 19 \\
\hline \multirow[t]{2}{*}{41.81} & 3 & Isopimaric acid & 128 & 120 \\
\hline & & Abietane-type resin acids & 1954 & 794 \\
\hline 42.07 & 4 & Di(dehydroabietic acid) & 18 & 4 \\
\hline 42.71 & 5 & Dehydroabietic acid & 954 & 452 \\
\hline 43.41 & 6 & Abietic acid & 62 & 14 \\
\hline 45.39 & 7 & $7 \beta$-Hydroxydehydroabietic acid & 99 & 39 \\
\hline 45.81 & 8 & $7 \alpha$-Hydroxydehydroabietic acid & 198 & 120 \\
\hline 46.50 & 9 & 7-Oxodehydroabietic acid & 179 & 57 \\
\hline 46.98 & 10 & 15-Hydroxydehydroabietic acid & 269 & 67 \\
\hline 49.86 & 11 & 7,15-Dihydroxydehydroabietic acid & 100 & 24 \\
\hline \multirow[t]{2}{*}{50.28} & 12 & 15-Hydroxy-7-oxodehydroabietic acid & 75 & 17 \\
\hline & & Monoterpenes & 55 & n.d. \\
\hline 7.86 & 13 & Camphor & 2 & n.d. \\
\hline 8.46 & 14 & Pinocarvone & 6 & n.d. \\
\hline 11.30 & 15 & Geraniol & 4 & n.d. \\
\hline 11.74 & 16 & Borneol & 10 & n.d. \\
\hline 14.08 & 17 & Myrtenol & 4 & n.d. \\
\hline 15.06 & 18 & $\alpha$-Terpineol & 13 & n.d. \\
\hline \multirow[t]{2}{*}{22.07} & 19 & Terpin & 16 & n.d. \\
\hline & & Sesquiterpenes & 32 & 5 \\
\hline 17.47 & 20 & Longifolene & 21 & 2 \\
\hline 22.67 & 21 & Caryophyllene oxide & 7 & 3 \\
\hline \multirow[t]{2}{*}{26.11} & 22 & Isolongifolol & 4 & n.d. \\
\hline & & Pentacyclic triterpenes & 425 & n.d. \\
\hline \multirow[t]{3}{*}{73.75} & 23 & Betulin & 425 & n.d. \\
\hline & & Aromatic compounds & 366 & 53 \\
\hline & & Aldehydes & 37 & 9 \\
\hline 15.83 & 24 & $p$-Hydroxybenzaldehyde & 4 & 3 \\
\hline \multirow[t]{2}{*}{20.97} & 25 & Vanillin & 33 & 6 \\
\hline & & Acids & 83 & 29 \\
\hline 28.39 & 26 & Vanillic acid & 6 & n.d. \\
\hline 31.85 & 27 & Syringic acid & 1 & n.d. \\
\hline 32.34 & 28 & (Z)-Ferulic acid & 3 & n.d. \\
\hline 32.87 & 29 & $p$-Coumaric acid & 8 & n.d. \\
\hline 36.51 & 30 & (E)-Ferulic acid & 58 & 29 \\
\hline \multirow[t]{2}{*}{38.07} & 31 & Caffeic acid & 7 & n.d. \\
\hline & & Resinols & 246 & 15 \\
\hline \multirow[t]{3}{*}{61.66} & 32 & Pinoresinol & 246 & 15 \\
\hline & & Fatty acids & 749 & 1146 \\
\hline & & Saturated fatty acids & 670 & 1058 \\
\hline 6.22 & 33 & Hexanoic acid & 3 & 4 \\
\hline 12.88 & 34 & Octanoic acid & 1 & 4 \\
\hline 16.27 & 35 & Nonanoic acid & 1 & 11 \\
\hline 19.51 & 36 & Decanoic acid & $\operatorname{tr}$ & 3 \\
\hline 30.87 & 37 & Tetradecanoic acid & 1 & 4 \\
\hline 33.38 & 38 & Pentadecanoic acid & 1 & 2 \\
\hline 35.79 & 39 & Hexadecanoic acid & 55 & 50 \\
\hline 37.46 & 40 & Heptadecanoic acid & 4 & 4 \\
\hline 40.30 & 41 & Octadecanoic acid & 23 & 42 \\
\hline 44.46 & 42 & Eicosanoic acid & 67 & 156 \\
\hline 48.32 & 43 & Docosanoic acid & 251 & 401 \\
\hline 50.14 & 44 & Tricosanoic acid & 30 & 36 \\
\hline 52.00 & 45 & Tetracosanoic acid & 213 & 326 \\
\hline 56.05 & 46 & Hexacosanoic acid & 20 & 15 \\
\hline
\end{tabular}


Table 1. Cont.

\begin{tabular}{|c|c|c|c|c|}
\hline RT (min) & No. & Compound & P. pinaster & P. pinea \\
\hline & & Unsaturated fatty acids & 75 & 80 \\
\hline 39.38 & 47 & (9Z,12Z)-Octadeca-9,12-dienoic acid & 22 & 11 \\
\hline 39.58 & 48 & (9Z)-Octadec-9-enoic acid & 48 & 39 \\
\hline 39.79 & 49 & (9E)-Octadec-9-enoic acid & 5 & 6 \\
\hline \multirow[t]{2}{*}{43.83} & 50 & (11Z)-Eicos-11-enoic acid & n.d. & 24 \\
\hline & & Diacids & 4 & 8 \\
\hline \multirow[t]{2}{*}{29.42} & 51 & Nonanedioic acid & 4 & 8 \\
\hline & & Long-chain aliphatic alcohols & 124 & 219 \\
\hline 33.94 & 52 & Hexadecan-1-ol & 11 & 8 \\
\hline 37.86 & 53 & Octadec-9-en-1-ol & 11 & 8 \\
\hline 38.57 & 54 & Octadecan-1-ol & 6 & 8 \\
\hline 46.78 & 55 & Docosan-1-ol & 34 & 71 \\
\hline \multirow[t]{3}{*}{50.47} & 56 & Tetracosan-1-ol & 62 & 124 \\
\hline & & Sterols & 587 & 242 \\
\hline & & $\Delta^{5}$-Sterols & 467 & 242 \\
\hline 60.66 & 57 & Campesterol & 33 & 18 \\
\hline \multirow[t]{2}{*}{62.73} & 58 & $\beta$-Sitosterol & 434 & 224 \\
\hline & & $\Delta^{4}$-3-keto-steroids & 120 & n.d. \\
\hline \multirow[t]{2}{*}{64.08} & 59 & Stigmast-4-en-3-one & $120^{2}$ & n.d. \\
\hline & & Others & 55 & 285 \\
\hline 14.22 & 60 & Glycerol & 3 & 7 \\
\hline 59.42 & 61 & 2,3-Dihydroxypropyl docosanoate & 52 & 91 \\
\hline \multirow[t]{2}{*}{64.08} & 62 & 2,3-Dihydroxypropyl tetracosanoate & 2 & 187 \\
\hline & & Total & 4746 & 2910 \\
\hline
\end{tabular}

${ }^{1}$ The results represent the average of the concordant values obtained for the two aliquots of the two extracts in each sample (less than $5 \%$ variation between aliquots of the same sample, and between extracts of the same sample). ${ }^{2}$ The sum of the content of stigmast-4-en-3-one (59) and 2,3-dihydroxypropyl tetracosanoate (62). Abbreviations: n.d., not detected; $\mathrm{tr}$, traces.

With respect to the identification of 7 $\beta$-hydroxy-DHAA (7) and $7 \alpha$-hydroxy-DHAA (8), both TMS derivatives exhibit a small molecular ion at $m / z 460$ and a fragment ion at $m / z 445$ in their MS spectra, corresponding to the loss of a methyl radical from the ionized TMS groups. Further ions at $m / z 191,234,237,252,299,370$, and 417 are also observed. The relative abundances of these fragments differ strongly between the two isomers, which allows for the unambiguous assignment of their structures [38]. The chromatographic elution order was also crucial together with the comparison between the obtained MS spectra and the ones found in the literature [38].

Most of the identified diterpenic compounds, such as DHAA (5), abietic acid (6), 7-oxo-DHAA (9), 15-hydroxy-DHAA (10), pimaric acid (1), sandaracopimaric acid (2), and isopimaric acid (3), have already been reported to be components of $P$. nigra bark [21], Turkish P. pinea bark [23], and Pakistani P. wallichiana, P. roxburghii, and P. gerardiana bark [25]. However, to the best of our knowledge, their presence in Portuguese P. pinaster bark and $P$. pinea bark has not been previously reported. 
<smiles>CC(C)C1=CC2=CC[C@H]3[C@@H](CO)CCC[C@]3(C)[C@H]2CC1</smiles>

Abietic acid

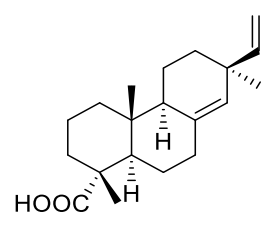

Pimaric acid

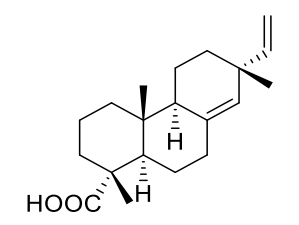

Sandaracopimaric acid

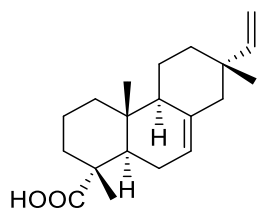

Isopimaric acid<smiles>CC(C)c1ccc2c(c1)CC[C@H]1[C@@H](O)CCC[C@]21CO</smiles><smiles>CO[C@H]1CC(=O)c2cc(C(C)C)ccc2[C@]2(C)CCC[C@@H](O)[C@H]12</smiles><smiles>COC[C@@H]1CC(O)c2cc(C(C)C)ccc2[C@]1(C)CC(=O)O</smiles>

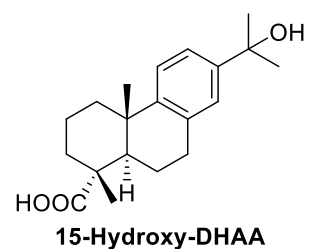

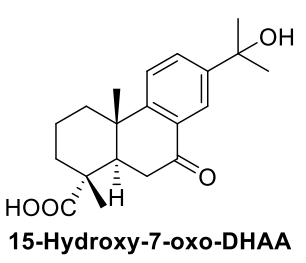<smiles>COCC[C@H]1CC(O)c2cc(C(C)(C)O)ccc2C12CCCC[C@H]2O</smiles>

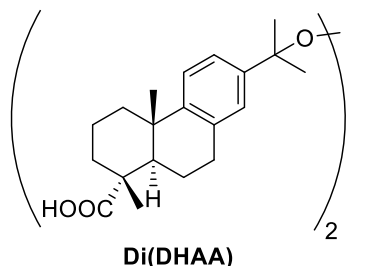

Figure 3. The chemical structures of the diterpenic resin acids found in the Portuguese P. pinaster and P. pinea barks.

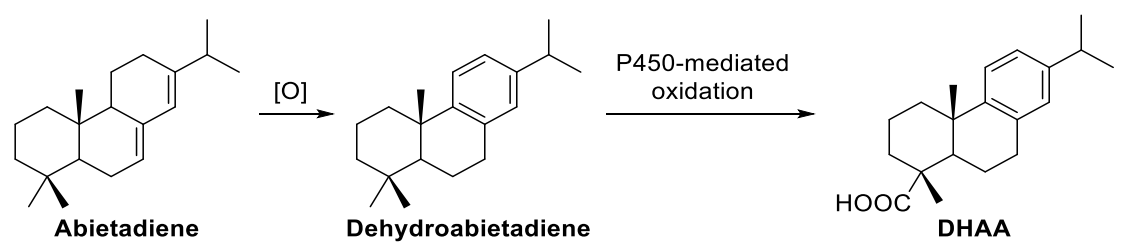

Scheme 1. The biosynthesis of DHAA.

The high abundance of DHAA and its oxidation derivatives adds value to these extracts, since they display important biological properties. For instance, DHAA (5) exhibits antiulcer, antimicrobial, antitumor, and anti-inflammatory effects [45]. Moreover, 7-oxo-DHAA (9) has shown contact allergenic properties, and 15-hydroxy-DHAA (10) and 15-hydroxy-7-oxo-DHAA (12) have shown anti-inflammatory activity.

Additionally, seven monoterpenes (13-19) and three sesquiterpenes (20-22) were detected at low abundances in the Portuguese P. pinaster bark, representing $1.9 \%$ and $1.1 \% w / w$ of the total terpene contents, respectively (Table 1). Terpin (19) was found to be the most abundant monoterpene (29\% $w / w$ of $P$. pinaster bark monoterpene content), whereas longifolene (20) was found to be the major sesquiterpene $(66 \% w / w$ of total sesquiterpene content). The identified mono- and sesquiterpenes are reported in this study for the first time to be constituents of $P$. pinaster bark. Monoterpenes are common components of pine wood turpentine [46], and, in particular, $\alpha$-terpineol (18) has been identified in P. pinea needles [20], whereas longifolene (20) has been identified in P. pinea wood [23]. As in the case of DHAA and its oxidized derivatives, terpin is a dehydrated monoterpene that is not naturally found in wood. Therefore, its abundance in bark extracts should be associated with exposure to an external environment. Finally, the low abundance of monoterpenes that was observed in both studied Pinus spp. can be justified by their possible loss during the drying and grinding processes. The methodology 
employed in the present work is not the most suitable for the characterization of their volatile fraction, which is beyond the scope of this work.

Betulin (23) was the single pentacyclic triterpene present in the P. pinaster bark lipophilic fraction, representing $15 \% w / w$ of the total terpene content (Table 1 ). Its identification was achieved through the detection of the molecular ion at $m / z 586$ from the corresponding TMS derivative, and the product ions common to the mass fragmentation of trimethylsilyl derivatives of lupane-type pentacyclic triterpenes, namely at $m / z 571\left(\left[\mathrm{M}-\mathrm{CH}_{3}\right]^{+}\right), 496\left([\mathrm{M}-\mathrm{TMSOH}]^{+}\right), 279,190$, and 189 as the base peak [47]. To the best of our knowledge, betulin (23) has been described herein for the first time in the bark of P. pinaster. Nevertheless, this compound has recently been detected in both the outer and inner bark of Pinus merkusii and the outer bark of Pinus montezumae [48]. The presence of this compound in P. pinaster bark can be an additional factor for exploiting this forest by-product, as it can be converted into betulinic acid, which exhibits several interesting biological properties, including Human Immunodeficiency Virus (HIV) inhibition, antimicrobial, and anti-inflammatory activity [49].

\subsubsection{Fatty Acids}

Nineteen fatty acids (33-51) were identified in the P. pinaster and P. pinea bark lipophilic extracts, accounting for $16 \%$ and $39 \% w / w$ of the total content of identified components, respectively (Table 1 ). Among the fatty acids, fourteen were saturated and four unsaturated, and their chain length varied between 6 and 26 carbon atoms. In both samples, the saturated fatty acids content was much higher than the unsaturated fatty acids content, ca. 8.9-fold and 13.2-fold for the P. pinaster and P. pinea bark lipophilic extracts, respectively. Indeed, docosanoic acid (43) was the major saturated fatty acid, whereas (9Z)-octadec-9-enoic acid (48) was the major unsaturated fatty acid. Considering the fatty acid composition of $P$. pinaster bark, all of the presented constituents of this family were herein identified for the first time, with the exception of tetradecanoic acid (37), hexadecanoic acid (39), and (9Z)-octadec-9-enoic acid (48) [50]. On the other hand, hexanoic acid (33), octanoic acid (34), nonanoic acid (35), decanoic acid (36), tricosanoic acid (44), hexacosanoic acid (46), and (11Z)-eicos-11-enoic acid (50) were identified for the first time in P. pinea bark in the present work.

\subsubsection{Sterols}

Two $\Delta^{5}$-sterols, namely campesterol (57) and $\beta$-sitosterol (58), and a $\Delta^{4}$-3-keto-steroid, named stigmast-4-en-3-one (59), were found, at lower abundances, in the P. pinaster and P. pinea bark lipophilic extracts (Table 1). Among these, $\beta$-sitosterol was found to be the major component in the studied Pinus bark samples. To the best of our knowledge, these sterols were also identified here for the first time in P. pinaster bark. On the other hand, campesterol (57) and $\beta$-sitosterol (58) have already been described as lipophilic components of $P$. pinea bark and wood [23].

\subsubsection{Aromatic Compounds}

Nine aromatic compounds (24-32) were analyzed in the P. pinaster and P. pinea bark lipophilic fractions, with concentrations ranging from $7.7 \%$ to $1.8 \% w / w$ of the total concentration of identified components (Table 1). Pinoresinol (32) was the major component of this class that was present in the P. pinaster bark. On the other hand, (E)-ferulic acid (30) was the major component in the P. pinea bark.

\subsubsection{Long-Chain Aliphatic Alcohols and Minor Compounds}

Low abundances of five LCAAs (52-56) were identified in the analyzed P. pinaster and P. pinea lipophilic extracts, representing $2.6 \%$ and $7.5 \% w / w$ of the total content of identified constituents, respectively (Table 1). The chain length of these compounds ranged from 16 to 24 carbon atoms, with octadec-9-en-1-ol (53) as the only unsaturated component of this subclass. Tetracosan-1-ol (56) was the major constituent of this lipophilic class in both of the Pinus lipophilic fractions. With the exception of hexadecan-1-ol (52) [50], the remaining LCAAs have been mentioned in the present work for the 
first time as constituents of bark from the Portuguese P. pinaster. For the P. pinea bark, the LCAAs hexadecan-1-ol (52) and octadec-9-en-1-ol (53) were herein found for the first time.

Finally, glycerol (60) and two monoglycerides (61 and 62) were found in the P. pinaster and P. pinea bark samples, representing $1.2 \%$ and $9.8 \% w / w$ of the total content of identified compounds, respectively (Table 1).

\section{Conclusions}

In conclusion, the Portuguese P. pinaster and P. pinea barks demonstrated a high abundance of diterpenic compounds, with abietic-type resin acids as the main constituents of this family. In particular, dehydroabietic acid was found to be the major resin acid component of these by-products, together with several oxidized DHAA derivatives, suggesting that extensive oxidation/dehydrogenation of naturally occurring abietane-type resin acids had taken place. In addition, aromatic compounds, long-chain aliphatic alcohols, fatty acids, and sterols were also identified at lower amounts. This study suggests that P. pinaster and P. pinea barks can be a good source of valuable diterpenic compounds for further nutraceutical applications. Finally, there is a commercially available bark extract from French maritime pine (Pycnogenol ${ }^{\circledR}$ ) that is rich in polyphenolic compounds, such as catechin, taxifolin, procyanidins, and phenolic acids. Due to the importance of phenolic compounds, new studies involving polar extracts from Portuguese P. pinaster and P. pinea bark will be performed next.

Author Contributions: Investigation and writing (original draft preparation), J.L.C.S. and P.A.B.R.; project administration, supervision, and writing (review and editing), C.S.R.F., A.M.S.S., and A.J.D.S.

Funding: This work was financed by Portugal 2020 through FEDER in the frame of POCI and in the scope of the projects: MultiBiorefinery (POCI-01-0145-FEDER-016403), CICECO-Aveiro Institute of Materials CTM/50011 (POCI-01-0145-FEDER-007679), and QOPNA Research Unit (UID/QUI/00062/2013). It was co-financed by FCT/MCTES.

Acknowledgments: Carmen Freire acknowledges FCT/MCTES for a contract under the program Investigador FCT 2012 (IF/01407/2012). Joana Sousa and Patrícia Ramos also acknowledge the MultiBiorefinery project (POCI-01-0145-FEDER-016403) for their post-doctoral grants.

Conflicts of Interest: The authors declare no conflict of interest.

\section{References}

1. ICNF. IFN6-Áreas dos Usos do solo e das Espécies Florestais de Portugal Continental em 1995, 2005 e 2010. Resultados Preliminares; ICNF: Lisboa, Portugal, 2013; pp. 1-34.

2. Figueiredo, A.C.; Pedro, L.G.; Barroso, J.G.; Trindade, H.; Sanches, J.; Oliveira, C.; Correia, M. Pinus pinaster Aiton e Pinus pinea L. Agrotec 2014, 12, 14-18.

3. ICNF. IFN5-5 $5^{\circ}$ Inventário Florestal Nacional. Relatório Final; p Table 309 (FloreStat App); ICNF: Lisboa, Portugal, 2010.

4. Clark, J.H.; Deswarte, F.E.I. The Biorefinery Concept-An Integrated Approach. In Introduction to Chemicals from Biomass; Clark, J., Deswarte, F., Eds.; John Wiley \& Sons, Ltd.: Hoboken, NK, USA, 2008; pp. 1-20.

5. Silvestre, A.J.D.; Gandini, A. Rosin: Major Sources, Properties and Applications. In Monomers, Polymers and Composites from Renewable Resources; Belgacem, M.N., Gandini, A., Eds.; Elsevier: Amsterdam, The Netherlands, 2008; pp. 67-88.

6. Keeling, C.I.; Bohlmann, J. Diterpene resin acids in conifers. Phytochemistry 2006, 67, 2415-2423. [CrossRef] [PubMed]

7. Feio, S.S.; Gigante, B.; Roseiro, J.C.; Marcelo-Curto, M.J. Antimicrobial activity of diterpene resin acid derivatives. J. Microbiol. Methods 1999, 35, 201-206. [CrossRef]

8. Feliciano, A.S.; Gordaliza, M.; Salinero, M.A.; del Corral, J.M.M. Abietane Acids: Sources, Biological Activities, and Therapeutic Uses. Planta Med. 1993, 59, 485-490. [CrossRef] [PubMed]

9. Gazim, Z.; Rodrigues, F.; Amorin, A.; Rezende, C.; Soković, M.; Tešević, V.; Vučković, I.; Krstić, G.; Cortez, L.; Colauto, N.; et al. New Natural Diterpene-Type Abietane from Tetradenia riparia Essential Oil with Cytotoxic and Antioxidant Activities. Molecules 2014, 19, 514-521. [CrossRef] [PubMed] 
10. González, M.A.; Correa-Royero, J.; Agudelo, L.; Mesa, A.; Betancur-Galvis, L. Synthesis and biological evaluation of abietic acid derivatives. Eur. J. Med. Chem. 2009, 44, 2468-2472. [CrossRef] [PubMed]

11. Lin, S.; Zhang, Y.; Liu, M.; Yang, S.; Gan, M.; Zi, J.; Song, W.; Fan, X.; Wang, S.; Liu, Y.; et al. Abietane and C20-Norabietane Diterpenes from the Stem Bark of Fraxinus sieboldiana and Their Biological Activities. J. Nat. Prod. 2010, 73, 1914-1921. [CrossRef] [PubMed]

12. Theoduloz, C.; Pertino, M.W.; Rodríguez, J.A.; Schmeda-Hirschmann, G. Gastroprotective Effect and Cytotoxicity of Carnosic Acid Derivatives. Planta Med. 2011, 77, 882-887. [CrossRef] [PubMed]

13. Yao, F.; Zhang, D.-W.; Qu, G.-W.; Li, G.-S.; Dai, S.J. New abietane norditerpenoid from Salvia miltiorrhiza with cytotoxic activities. J. Asian Nat. Prod. Res. 2012, 14, 913-917. [CrossRef] [PubMed]

14. Yang, N.-Y.; Liu, L.; Tao, W.-W.; Duan, J.-A.; Tian, L.-J. Diterpenoids from Pinus massoniana resin and their cytotoxicity against A431 and A549 cells. Phytochemistry 2010, 71, 1528-1533. [CrossRef] [PubMed]

15. Kolak, U.; Kabouche, A.; Öztürk, M.; Kabouche, Z.; Topçu, G.; Ulubelen, A. Antioxidant diterpenoids from the roots of Salvia barrelieri. Phytochem. Anal. 2009, 20, 320-327. [CrossRef] [PubMed]

16. Zhang, G.-J.; Li, Y.-H.; Jiang, J.-D.; Yu, S.-S.; Qu, J.; Ma, S.-G.; Liu, Y.-B.; Yu, D.-Q. Anti-Coxsackie virus B diterpenes from the roots of Illicium jiadifengpi. Tetrahedron 2013, 69, 1017-1023. [CrossRef]

17. Arrabal, C.; García-Vallejo, M.C.; Cadahia, E.; Cortijo, M.; de Simón, B.F. Characterization of two chemotypes of Pinus pinaster by their terpene and acid patterns in needles. Plant Syst. Evol. 2012, 298, 511-522. [CrossRef]

18. Arrabal, C.; García-Vallejo, M.C.; Cadahia, E.; Cortijo, M.; de Simón, B.F. Seasonal variations of lipophilic compounds in needles of two chemotypes of Pinus pinaster Ait. Plant Syst. Evol. 2014, 300, 359-367. [CrossRef]

19. Conde, E.; Fang, W.; Hemming, J.; Willför, S.; Domínguez, H.; Parajó, J.C. Recovery of bioactive compounds from Pinus pinaster wood by consecutive extraction stages. Wood Sci. Technol. 2014, 48, 311-323. [CrossRef]

20. De Simón, B.F.; Vallejo, M.C.G.; Cadahía, E.; Miguel, C.A.; Martinez, M.C. Analysis of lipophilic compounds in needles of Pinus pinea L. Ann. For. Sci. 2001, 58, 449-454. [CrossRef]

21. Hafizoğlu, H.; Holmbom, B.; Reunanen, M. Chemical Composition of Lipophilic and Phenolic Constituents of Barks from Pinus nigra, Abies bornmülleriana and Castanea sativa. Holzforschung 2002, 56, 257-260. [CrossRef]

22. Koutsaviti, A.; Ioannou, E.; Couladis, M.; Tzakou, O.; Roussis, V. ${ }^{1} \mathrm{H}$ and ${ }^{13} \mathrm{C}$ NMR spectral assignments of abietane diterpenes from Pinus heldreichii and Pinus nigra subsp. nigra. Magn. Reson. Chem. 2017, 55, 772-778. [CrossRef] [PubMed]

23. Hafızoğlu, H. Studies on the Wood and Bark Constituents of Pinus pinea L. Holzforschung 1989, 43, 41-43. [CrossRef]

24. Conde, E.; Hemming, J.; Smeds, A.; Reinoso, B.D.; Moure, A.; Willför, S.; Domínguez, H.; Parajó, J.C. Extraction of low-molar-mass phenolics and lipophilic compounds from Pinus pinaster wood with compressed $\mathrm{CO}_{2}$. J. Supercrit. Fluids 2013, 81, 193-199. [CrossRef]

25. Willför, S.; Ali, M.; Karonen, M.; Reunanen, M.; Arfan, M.; Harlamow, R. Extractives in bark of different conifer species growing in Pakistan. Holzforschung 2009, 63, 551-558. [CrossRef]

26. Fradinho, D.M.; Neto, C.P.; Evtuguin, D.; Jorge, F.C.; Irle, M.A.; Gil, M.H.; de Jesus, J.P. Chemical characterisation of bark and of alkaline bark extracts from maritime pine grown in Portugal. Ind. Crop. Prod. 2002, 16, 23-32. [CrossRef]

27. Nunes, E.; Quilhó, T.; Pereira, H. Anatomy and Chemical Composition of Pinus Pinaster Bark. IAWA J. 1996, 17, 141-150. [CrossRef]

28. Nunes, E.; Quilhó, T.; Pereira, H. Anatomy and chemical composition of Pinus pinea L. bark. Ann. For. Sci. 1999, 56, 479-484. [CrossRef]

29. Kettunen, H.; van Eerden, E.; Lipiński, K.; Rinttilä, T.; Valkonen, E.; Vuorenmaa, J. Dietary resin acid composition as a performance enhancer for broiler chickens. J. Appl. Anim. Nutr. 2017, 5, 1-8. [CrossRef]

30. Kettunen, H.; Vuorenmaa, J.; Rinttilä, T.; Grönberg, H.; Valkonen, E.; Apajalahti, J. Natural resin acid-enriched composition as a modulator of intestinal microbiota and performance enhancer in broiler chicken. J. Appl. Anim. Nutr. 2015, 3, 1-9. [CrossRef]

31. Roy, K.; Lyhs, U.; Vuorenmaa, J.; Pedersen, K. In vitro inhibition studies of natural resin acids to Clostridium perfringens, Staphylococcus aureus and Escherichia coli O149. J. Appl. Anim. Nutr. 2018, 5, 1-5. [CrossRef]

32. Freire, C.S.R.; Silvestre, A.J.D.; Neto, C.P. Identification of New Hydroxy Fatty Acids and Ferulic Acid Esters in the Wood of Eucalyptus globulus. Holzforschung 2002, 56, 143-149. [CrossRef] 
33. Villaverde, J.J.; Domingues, R.M.A.; Freire, C.S.R.; Silvestre, A.J.D.; Neto, C.P.; Ligero, P.; Vega, A. Miscanthus $\times$ giganteus Extractives: A Source of Valuable Phenolic Compounds and Sterols. J. Agric. Food Chem. 2009, 57, 3626-3631. [CrossRef] [PubMed]

34. Aveling, E.M.; Heron, C. Identification of Birch Bark Tar at the Mesolithic Site of Star Carr. Anc. Biomol. 1998, 2, 69-80.

35. Birkemeyer, C.; Kopka, J. Design of Metabolite Recovery by Variations of the Metabolite Profiling Protocol. In Concepts in Plant Metabolomics; Nikolau, B.J., Wurtele, E.S., Eds.; Springer: Dordrecht, The Netherlands, 2007; pp. 45-70.

36. Brettell, R.C.; Schotsmans, E.M.J.; Walton Rogers, P.; Reifarth, N.; Redfern, R.C.; Stern, B.; Heron, C.P. 'Choicest unguents': Molecular evidence for the use of resinous plant exudates in late Roman mortuary rites in Britain. J. Archaeol. Sci. 2015, 53, 639-648. [CrossRef]

37. Coelho, D.; Marques, G.; Gutiérrez, A.; Silvestre, A.J.D.; del Río, J.C. Chemical characterization of the lipophilic fraction of giant reed (Arundo donax) fibres used for pulp and paper manufacturing. Ind. Crops Prod. 2007, 26, 229-236. [CrossRef]

38. Rontani, J.-F.; Aubert, C.; Belt, S.T. EIMS Fragmentation Pathways and MRM Quantification of $7 \alpha / \beta$-Hydroxy-Dehydroabietic Acid TMS Derivatives. J. Am. Soc. Mass Spectrom. 2015, 26, 1606-1616. [CrossRef] [PubMed]

39. Santos, S.A.O.; Vilela, C.; Domingues, R.M.A.; Oliveira, C.S.D.; Villaverde, J.J.; Freire, C.S.R.; Neto, C.P.; Silvestre, A.J.D. Secondary metabolites from Eucalyptus grandis wood cultivated in Portugal, Brazil and South Africa. Ind. Crop. Prod. 2017, 95, 357-364. [CrossRef]

40. Szczepaniak, L.; Isidorov, V.A. Gas chromatographic retention indices of trimethylsilyl derivatives of terpene alcohols. J. Chromatogr. A 2011, 1218, 7061-7064. [CrossRef] [PubMed]

41. Van den Berg, K.J.; Boon, J.J.; Pastorova, I.; Spetter, L.F.M. Mass spectrometric methodology for the analysis of highly oxidized diterpenoid acids in Old Master paintings. J. Mass Spectrom. 2000, 35, 512-533. [CrossRef]

42. Costa, P.; Grosso, C.; Gonçalves, S.; Andrade, P.B.; Valentão, P.; Gabriela Bernardo-Gil, M.; Romano, A. Supercritical fluid extraction and hydrodistillation for the recovery of bioactive compounds from Lavandula viridis L'Hér. Food Chem. 2012, 135, 112-121. [CrossRef]

43. Flores, R.M.; Doskey, P.V. Evaluation of multistep derivatization methods for identification and quantification of oxygenated species in organic aerosol. J. Chromatogr. A 2015, 1418, 1-11. [CrossRef] [PubMed]

44. Costa, M.S.; Rego, A.; Ramos, V.; Afonso, T.B.; Freitas, S.; Preto, M.; Lopes, V.; Vasconcelos, V.; Magalhães, C.; Leão, P.N. The conifer biomarkers dehydroabietic and abietic acids are widespread in Cyanobacteria. Sci. Rep. 2016, 6, 1-11. [CrossRef] [PubMed]

45. González, M.A. Aromatic abietane diterpenoids: Their biological activity and synthesis. Nat. Prod. Rep. 2015, 32, 684-704. [CrossRef]

46. Silvestre, A.J.D.; Gandini, A. Terpenes: Major Sources, Properties and Applications. In Monomers, Polymers and Composites from Renewable Resources; Belgacem, M.N., Gandini, A., Eds.; Elsevier: Amsterdam, The Netherlands, 2008; pp. 17-38.

47. Mathe, C.; Culioli, G.; Archier, P.; Vieillescazes, C. Characterization of archaeological frankincense by gas chromatography-mass spectrometry. J. Chromatogr. A 2004, 1023, 277-285. [CrossRef] [PubMed]

48. Masendra; Ashitani, T.; Takahashi, K.; Lukmandaru, G. Lipophilic extractives of the inner and outer barks from six different Pinus species grown in Indonesia. J. For. Res. 2018, 29, 1329-1336. [CrossRef]

49. Domingues, R.M.A.; Guerra, A.R.; Duarte, M.; Freire, C.S.R.; Neto, C.P.; Silva, C.M.S.; Silvestre, A.J.D. Bioactive Triterpenic Acids: From Agroforestry Biomass Residues to Promising Therapeutic Tools. Mini-Rev. Org. Chem. 2014, 11, 382-399. [CrossRef]

50. Braga, M.E.M.; Santos, R.M.S.; Seabra, I.J.; Facanali, R.; Marques, M.O.M.; de Sousa, H.C. Fractioned SFE of antioxidants from maritime pine bark. J. Supercrit. Fluids 2008, 47, 37-48. [CrossRef]

(C) 2018 by the authors. Licensee MDPI, Basel, Switzerland. This article is an open access article distributed under the terms and conditions of the Creative Commons Attribution (CC BY) license (http:/ / creativecommons.org/licenses/by/4.0/). 